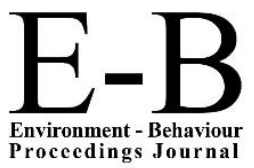

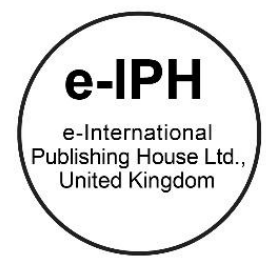

\title{
In Search of Home Sweet Home: Between theory and reality
}

\author{
Nuraisyah Chua Abdullah¹, Ramzyzan Ramly², Muhammad Izwan Ikhsan ${ }^{3}$ \\ 1 Faculty of Law, Universiti Teknologi MARA, Shah Alam, 40450, Malaysia \\ 2 Faculty of Mechanical Engineering, Universiti Teknologi MARA, Shah Alam, 40450, Malaysia \\ ${ }^{3}$ Department of Law Enforcement, Vision College, Kelana Jaya, 47301, Malaysia \\ nuraisyah@salam.uitm.edu.my \\ Tel: 60355441083
}

\begin{abstract}
Houses bought through sub-sale contract are of varying quality. The "caveat emptor" doctrine compels the purchaser to make a thorough investigation in a sub-sale house purchase. The "as is" clause posits that the house is sold based on its existing conditions. This paper analyses the application of the "caveat emptor" and "as is" clause in Malaysia and highlights the framework of information disclosure on property conditions in Malaysia, in comparison with the vendor disclosure laws in the United States and Australia. This paper suggests that a pre-purchase checklist should be provided in a sale and purchase transaction.
\end{abstract}

Keywords: sub-sale of houses; caveat emptor; "as is" clause; vendor disclosure law

eISSN: 2398-4287@ 2017. The Authors. Published for AMER ABRA by e-International Publishing House, Ltd., UK. This is an open access article under the CC BYNCND license (http://creativecommons.org/licenses/by-nc-nd/4.0). Peer-review under responsibility of AMER (Association of Malaysian Environment-Behaviour Researchers), ABRA (Association of Behavioural Researchers on Asians) and cE-Bs (Centre for Environment-Behaviour Studies), Faculty of Architecture, Planning \& Surveying, Universiti Teknologi MARA, Malaysia.

https://doi.org/10.21834/e-bpj.v2i6.964

\subsection{Introduction}

Everyone dreams of getting a quality residential property to be able to enjoy a better quality of life. According to Mohamad et al. (2017), the quality of the houses largely depends on factors such as functionality, presentation and appearance, environment, and amenities. In Malaysia, certain laws, regulations, and standards regulate the housing industry to ensure that residential properties bought by purchasers are built according to the acceptable standards. Wena et al. (2017) highlight that in Malaysia, many criticisms have been levelled to the problems in workmanship performance, construction processes, the organisations involved, the materials, etc. in the construction industry. These elements were under enormous pressure for better building quality. As for newly constructed residential properties, the Housing Development (Control and Licensing) Act 1966 is a legislative measure to protect buyers from residential properties of inferior quality, which falls below the acceptable standard. Besides, the Act also creates a Tribunal for Homebuyers Claim, which is empowered to determine disputes between a residential property buyer and the developer, including on matters about the quality of the residential property and poor workmanship (Sufian \& Rahman, 2008). By contrast, buyers of sub-sale residential properties do not enjoy such protection under the law. Saleh et al. (2017) observe that there is housing mismatch in Malaysia and the problem of affordability of the newly constructed houses. Most people from the middle-income group, are trapped in the range of middle group requirement, where they are not qualified to buy newly built low and medium cost houses. This paper submits that due to the unaffordability of new homes, these people must turn to the sub-sale market for second-hand residential properties. The "caveat emptor" doctrine compels the buyer to make a thorough investigation and to blame himself if a defect is found

eISSN: 2398-4287C 2017. The Authors. Published for AMER ABRA by e-International Publishing House, Ltd., UK. This is an open access article under the CC BYNCND license (http://creativecommons.org/licenses/by-nc-nd/4.0/). Peer-review under responsibility of AMER (Association of Malaysian Environment-Behaviour Researchers), ABRA (Association of Behavioural Researchers on Asians) and cE-Bs (Centre for Environment-Behaviour Studies), Faculty of Architecture, Planning \& Surveying, Universiti Teknologi MARA, Malaysia.

https://doi.org/10.21834/e-bpj.v2i6.964 
due to his carelessness, in the absence of fraud or misrepresentation by the vendor. Meanwhile, the "as is, where is" clause in the sale and purchase agreement posits that the residential property is sold based on its conditions, that the buyer is ready to buy it "with all faults", whether immediately apparent to the customer's eyes (Amstrong \& Block, 2007). The combined effect of "caveat emptor doctrine and "as is" clause works to relieve the vendor of continuing legal liability after the closing of the contract, but at the same time causes great distress and nightmare to the buyer of a defective sub-sale residential property. Poor housing conditions not only affect one's quality of life but can also negatively impact the cognitive condition and decline of sensory abilities, in particular for the elderly (Dayaratne, 2016). Poor and substandard building conditions also lead to serious consequences such as collapsed buildings, and severe damage to the buildings (Egercioglu et al., 2015). As Malaysian law on sub-sale of residential property still hinges on the doctrine of "caveat emptor" and "as is" clause, as evident in the judicial decisions, leading to difficulty in search of a dream home, as compared to the vendor disclosure laws in the United States and Australia, this paper aims to illustrate the problems faced by buyers of sub-sale residential properties and advocate for possible legal solutions.

\section{0 "Caveat Emptor" Doctrine vs Vendor Disclosure Duty}

The traditional doctrine of "caveat emptor" stipulates that in the absence of express agreement, a vendor is not liable to the purchaser for the conditions of the property and owes no obligation whatsoever to disclose anything to the purchaser (Geltman, 2000). As will be discussed later, the purchaser must prove that there is active concealment of the defect by way of fraud or misrepresentation on the part of the vendor. If the transferee fails to do so, he has no recourse to claim damages from the seller when the defect is discovered after the contract has been closed (Carper \& McKinsey, 2011).

Unlike Malaysia, in other jurisdictions, there is a gradual positive shift in favour of protecting the interest of the property purchasers. Courts in multiple occasions have declared that implied warranty, in fact, exist in property transactions. The Courts also imposed the duty on the vendors to disclose to the purchasers, defect known to them before the signing of the sale and purchase agreement (herein after referred to as the SPA). In jurisdictions like the United States and Australia, the judicial activism in favour of implied warranty and seller's common law duty of disclosure appears in the statutory form. For instance, in the United States, in the Californian case of Easton v Stassburger (1984) 152 Cal. App. 3d 90, the Court declared that the broker must disclose to a purchaser material defects known to the broker but unknown to and unobservable by the buyer. The court thus held that the brokers, in this case, had a duty to warn purchasers of potentially serious soil problems. The brokers were negligent when they failed to disclose defects, which could have been discovered through reasonable diligence. Meanwhile, in the case Miles v McSwegin (1979) 58 Ohio St. 2d 97 , the Supreme Court of Ohio observed that the seller's broker was found liable for misrepresentation. In this case, the broker told the purchasers that the premises were "a good solid home" and the property had been treated for termite infestation without disclosing this treatment to the buyers.

Similarly, in Australia, the judicial view has shifted from "caveat emptor" to the idea of protecting the purchasers. In the Western Australian case of Franich v Swannell (1993) 10 WAR 459, the Court held that failure to disclose the existence of termite damage or current infestations where this information was known to the seller entitled the purchaser to damages. Meanwhile, in the South Australian case of Mitchell \& Anor v Valherie [2005] SASC 350, the seller was found liable for failure to disclose structural defects in the building. In the Victorian case of Walker v Masillamani [2007] VSC 172, the Supreme Court of Victoria held that the plaintiffs were entitled to damages because the house was not of sound construction and there was something wrong in that the house had suffered extensive termite damage. The defendants fraudulently concealed the fact that termites ate the floorboards, bearers, and joists in the house. The defendants tried to conceal the termite damage by covering the floorboards with carpet.

Legislative drive in the United States and Australia has accompanied judicial recognition of the duty of the vendor to disclose and the restriction of the application of the "caveat emptor" doctrine. In California, section 1102.3 of the Civil Code provides that the transferor of any real property must deliver to the prospective transferee the written statement required by this Code. In Oklahoma, section 833(A)(2) of the Residential Property Condition Disclosure Act 1995 provides that a seller of property located in must deliver to the purchaser a written property condition disclosure statement on a form established by the Oklahoma Real Estate Commission. Similarly, by section 765.20 of the Illinois Residential Real Property Disclosure Act 1994, a seller of residential real property shall complete all applicable items in the disclosure document described in section 35 of the Act. In Australia, similar provisions are also available in Tasmania, South Australia, and Australian Capital Territory. In Tasmania, section 86(1) of the Property Agents and Land Transactions Act 2005 provides that when advertising residential land for sale, a vendor or any agent of the vendor must ensure that the relevant disclosure documents are available to a purchaser. Meanwhile, section 7(1) of the Land and Business (Sale and Conveyancing) Act 1994, South Australia requires the vendor of land to serve, or cause to be served, on the purchaser a statement in the form required by regulation. In the Australian Capital Territory, a disclosure statement is required under section $67(1)$ of the Community Title Act 2001.

In Malaysia, by contrast, the "caveat emptor" doctrine in its original form still stands firm. The Court in Hadland Arthur John and Anor v Audra Elaine Gomez [2009] MLJU 736 made an unequivocal declaration that the general principle governing the purchase of landed properties in Malaysia is "caveat emptor". The Court further emphasised that the seller has no legal duty to disclose any defects and makes no warranty about the state and condition of the property being sold. The Court disallowed the plaintiffs' application to rescind the contract, on the grounds of physical defect of the residential property, because such warranty was not expressly provided in the SPA. The unsympathetic judicial stance continues in the case of Wong Soon Hoo dan Satu Lagi Iwn Sumbangan Daya Sdn Bhd [2010] 9 MLJ 559, where the Court reiterated that the law concerning the purchase of real property in Malaysia is "caveat emptor". The Court highlighted two instances whereby the purchasers had the opportunity to inspect whether the premises have two 
bathrooms - an essential element of a house as was underscored by Mohit and lyanda (2017), but they failed to do so. The maxim of "vigilantibus et non dormientibusjurasubveniunt" (the law aids the vigilant and not the indolent) work in disfavour of the imprudent purchasers.

As shown above, Malaysian law remains static around "caveat emptor" in real estate transactions. While other jurisdictions have acknowledged the implied warranty that a residential property must be fit for habitation and imposes a duty on the seller to disclose material conditions that would affect the buyer's decision to buy, that has not been the case for Malaysia. The purchaser must prove the existence of fraud or misrepresentation to claim exemption from the "caveat emptor" doctrine. He will not be compensated for any defect found in the property after the SPA has been closed if he fails to prove the fraud or misrepresentation.

\subsection{Fraud and Misrepresentation: Evidential Difficulty}

As stated above, the only exception to the stringent "caveat emptor" doctrine is vendor fraud and misrepresentation. Fraud arises when the vendor makes a false statement as to a material fact, which he knows to be false, and the purchaser relies on the statement to his detriment. To constitute fraud, it requires intent (Hamilton, 2015). Intent can be proved through the concealment of defective conditions by disguising them, covering them up, or otherwise preventing purchasers from discovering them (Weinberger, 1996). For example, in Mitchell v Skubiak 618 N.E. 2d 1013 (1993), the Illinois Appeal Court held that the vendor could not rely on the doctrine of "caveat emptor" as indoor-outdoor carpeting glued to porch and steps were meant to conceal structural damage in the premises from the buyer's knowledge. Similarly, in Barylski v. Andrews, 439 S.W.2d 536, 540 (Mo. Ct. App. 1969), it was held that "caveat emptor" did not apply as there was sufficient evidence that the seller concealed the fire damage by paint, paper, plaster, and wallboard.

As noted by Marsh and Solloway (2005), plaintiffs who pursue a fraud claim against vendors face evidential difficulty in proving fraud and vendor's knowledge of the defect to the satisfaction of the court. In Kashman v Haas 766 N.E.2d 417 (Ind. Ct. App. 2002), the buyer sued the seller because the residential property contained extensive termite damage which he claimed the seller failed to disclose before the purchase. The Court emphasised that to succeed on the fraud claim, the vendor must have knowledge of the defect and actively concealed the defect from the buyer. Since the purchaser failed to adduce any evidence that the vendor knew of the termite damage, the fraud claim failed. As for the claim on the ground of misrepresentation, although it does not require the purchaser to prove fraud, he must show that the misrepresentation was intentional and due to reliance on the misrepresentation, he suffered damage (Bearman Jr, 1960). For instance, in Suraci v Ball 51 A.2d 404 (Pa. Super. Ct. 1946), the court took side with the purchaser when the agent misrepresented about the amount of taxes payable by the buyer as the agent had assured the buyer that "he had made a check of the taxes upon the property". In fact, the real amount was significantly higher than what had been represented by the agent.

Nonetheless, it must be borne in mind that when a party relies on his investigation and inspection of the property, irrespective of the vendor's representations, he cannot claim to have been misled by the fraudulent statements (Rosenthal \& Phillips, 1996). For instance, in Heifetz v. Bell, 101 Cal. App. 2d 275, 277, 225 P.2d 231 (1950), the Court observed that before making the purchase appellant Heifetz made an independent investigation of the neighbourhood. He also viewed the lot in question; checked the number of vehicles parked there; noted its possible capacity, and also made computations as to the probable revenue from the business. Given such evidence, the court was privileged to disbelieve appellant Heifetz's testimony that he relied on any representations of the respondent.

Similarly, in the case of Biegler v Stacy, (1995), 172 A.R. 57, the Alberta Provincial Court held that to succeed in a claim for misrepresentation, the purchaser must prove that the problem complained of is a latent defect. The defect must not be discoverable from due inspection, the vendor actively conceals the defect, and the latent defect must directly relate to the fitness of the house for habitation. Likewise, in the Australian case of Kadissi v Jankovic [1987] VR 255, the plaintiffs entered into a contract to purchase a flat from the defendant and paid a deposit. Before they entered into the contract, the plaintiffs had noticed some minor cracks in the internal wall of the flat. In fact, there were serious cracks in the external walls of the building. Unknown to the plaintiffs, extensive engineering work had been carried out to stop movement in the foundations. The Supreme Court of Victoria held that in the absence of fraudulent concealment or of misrepresentation or of an express agreement, a vendor of real estate is not liable to a purchaser for defects in a building or land rendering it dangerous or unfit for occupation. The seller is still not liable even if he has created the defects himself or is aware of their existence. The applicants were therefore not entitled to rescind the contract on the grounds of nondisclosure by the vendor of matters relating to the physical condition of the property. The problem with the building was self-evident having regard to the cracks that were so large, of such number and so placed. It must be inferred they were seen by the applicants on inspections of the property before entering into the contract. The problem was thus a patent and not latent one, so there could not, therefore, have been any nondisclosure.

In the Malaysian case of Wei Tah Construction (B) Co Sdn Bhd \& Anor v Law Wun Ing [1981] 2 MLJ 157, the buyer bought a land described as "near Sibu airport". Before the purchase, he instructed his solicitor to conduct a title search. The lawyer advised the buyer that it was a good buy. The purchaser did not physically inspect the property. Later, the buyer discovered that the land was in fact 8 to 9 miles from Sibu airport. The High Court of Kuching observed that even if the plaintiff relied on the description of the land as "near Sibu airport" which induced him to purchase it, it was apparent from the evidence that the seller did not mislead him. The plaintiff had earlier instructed his solicitor to investigate that title. In consequence of this investigation, he was advised that the Sibu land was a good buy. Besides, the defect which the plaintiff sought to rely upon was a patent defect of quality of the land he purchased which was discoverable by inspection and ordinary vigilance on the part of the purchaser. In this case, the plaintiff purposely chose not to inspect 
the land before executing the transfer with the first defendant because of his other considerations in making a quick profit. In this regard, he could not complain about discovering the defects after the contract has been closed.

As shown above, although fraud and misrepresentation can be grounds for the purchasers to sue sellers upon finding of a defect in purchased properties, fraud requires proof that the defect must be a latent one, and the seller knows of the defect and actively conceals it. Additionally, the buyer bears the burden to prove misrepresentation or fraud to the court. Although misrepresentation does not require proof of fraud, the aggrieved purchaser must show to the court that the misrepresentation was intentional. Besides, the rule that bars the purchasers' recovery for damages if the purchasers could discover the defect through their inspections but decided to rely on the vendors' representation further restricts the purchasers' legal recourse for remedies.

\section{0 "As Is Where Is" Clause: Where Is the Protection?}

Unlike the sale and purchase agreement between a developer and a purchaser, which is governed by the standard agreement under the Housing Development (Control and Licensing) Act 1966, a sub-sale residential property purchase agreement is not governed by any specific legislative measures. The sub-sale residential sale and purchase agreement are based on the freedom of contract concept where it is subject to the individual negotiated terms and conditions set by both the vendor and purchaser. Suffian LP in SEA Housing Corp Sdn Bhd v Lee Poh Choo [1982] 2 MLJ 31 revealed that when the government started giving housing loans making it possible for public servants to borrow money at $4 \%$ interest per annum to buy homes, there was an upsurge in demand for housing. To protect home buyers, most of whom are people of modest means, from rich and powerful developers, Parliament found it necessary to regulate the sale of houses and protect buyers by enacting the Act. According to Yok (1999) and Buang (2016), the standard forms in Schedule $\mathrm{G}$ (new landed properties) and Schedule $\mathrm{H}$ (building for subdivision into parties) were incorporated into the Act to protect consumers from housing developers that would create a one-sided contract and give "take it or leave it" treatment to the purchasers as well as abandoned housing projects. Sadly, the standard forms are only applicable to newly built houses. Purchases from the sub-sale market of completed houses are not within the scope of the Housing Development (Control and Licensing) Act 1966. In the sub-sale of properties, the terms of the contracts are ideally to be negotiated between the sellers and purchasers. However, in reality, in most cases, the purchasers are not of equal standing and not in a position to bargain the terms with the vendors (Cameron, 2000).

In sub-sale residential property purchase agreements, the "as is where is clause" is a common practice among vendors to indicate purchasers' acceptance of the properties as the way it is, as they are without any obligation to make repairs. Another aim of the clause is to make the buyers assume all obligations for any repairs or replacement so that the properties are habitable and fit for the intended purpose of the buyers (Roark \& Roark, 2013). "As is" clauses in contracts, including the sale of real property, allocate the risk of loss arising from conditions unknown to the parties, to bar claims of mutual mistake. These types of clauses in contracts for the sale of real property transfer the risk of loss where there is a defect that reasonably should have been discovered upon inspection but was not. The only time the risk of loss is not transferred is when a vendor makes fraudulent representations before the vendee signs a binding agreement as discussed earlier. A vendor's knowledge of a prior defect is essential to finding a deliberate concealment of a material fact. There can be no recovery where a plaintiff sustains damage through his or her acts or omissions, and not because of any reliance on the alleged fraudulent representations of the defendant or defendants, which the plaintiff did not believe (Cojocaz, 2005).

In the American case Prudential Insurance Company of America v. Jefferson Associates, Ltd., 896 S.W. 2d 156 (Tex. 1995), the Court decided in favour of the seller and the "as is" clause. This case arises from the sale of the Jefferson Building, a four-story commercial office building in Austin, Travis County, Texas. In late 1983, the Prudential Insurance Company of America (Prudential), after becoming, the owner of the Jefferson Building (through foreclosure), proposed to sell it to Jefferson Associates, a limited partnership, and F. B. Goldman (collectively, Goldman). Two years after the sale was consummated, Goldman discovered that the building contained asbestos. The Court observed that the plaintiff's agreement to buy the defendant's building "as is" precludes him from claiming that defendant's conduct caused him any harm when he found asbestos-containing material in the building. By agreeing to purchase something "as is", a buyer agrees to make his appraisal of the bargain and to accept the risk that he may be wrong. The sole cause of a buyer's injury in such circumstances, by its admission, is the buyer himself, who failed to inspect the property. There is no evidence that the defendant interfered with the plaintiff's inspection in any way.

In Malaysia, the application of "as is" clause can be seen in the case of Hadland Arthur John and Anor v Audra Elaine Gomez [2009] MLJU 736. This is a case where after the plaintiffs purchased the property from the defendant, the part of the plastic ceiling in the master bedroom of the property collapsed. The Court referred to Clause 11.2 (b) of the SPA which states that the property was purchased on an "as is where is" basis. The Court held that such clause excludes any warranty or condition as to the state and condition of the property and also, in consequence, its fitness for habitation. The plaintiffs were not entitled to rescind the contract despite physical defect found on the property. Relying on Clause 11.2(b) of the SPA the court held that there was no express warranty or condition that the property was fit for occupation. It can be seen from Hadland's case that once there is "as is" clause in the SPA, there is not much legal protection available to the buyers. Therefore, purchasers are advised to conduct inspections and due diligence on any property intended to be purchased before signing a SPA that contains the "as is" clause so as not to be caught in a similar predicament as in Hadland (Leong, 2011). 


\subsection{Current Regime of Information Availability: Its Inadequacy}

Unlike countries like the United States and Australia, in Malaysia, there is no legislation on vendor disclosure law in Malaysia, which obligates the vendor to disclose certain information to the property buyers before the sale. Hence, prospective buyers in Malaysia must rely on scattered sources of information such as the land title search, valuation report prepared by valuers and building inspection report made by building surveyors.

As regard to the title search, the National Land Code 1965 (from now on referred to as the NLC) provides for private and official search. As for private search, the applicant can inspect and take notes of or extracts from any register of title, presentation book or correction notebook maintained by the Register. The applicant can also take notes from any instrument of dealing presented, made to or in the custody of the Registrar (section $384 \mathrm{NLC}$ ). Regarding the official search, the applicant can do more than in the private search. Here, the applicant will be issued a certificate of search. The certificate specifies the person or body for the time being registered as proprietor of the land. If he is registered such as the trustee or as representative, it will be indicated in the certificate. Besides, it also summarises all memorials and other entries on the register document of title and specifies the express conditions and restrictions in interest to which the land is subject (section $385 \mathrm{NLC}$ ). Information upon title search in Malaysia is very limited as compared to other countries such as Hong Kong, Singapore, Victoria, Ontario, and the United States. While some other countries require unpaid taxes, notice of intention to acquire the land, and notice of unauthorised building work to be registered in the land title, Malaysia's land law regime does not require so. In comparison with other jurisdictions, the information system in the United States. Provides the most comprehensive information. Although other jurisdictions unveil more information upon title search, this paper argues that vendor disclosure information law appears to be necessary because title search alone does not provide details as to the conditions of the property, for example - the building or property layout plan built materials, architectural and engineering details of the property. As highlighted by Abdullah et al. (2016), Malaysians are concerned about the development plans of their vicinity. However, information about the development plans is not available via title search in Malaysia. The local council holds the information, not the land office. This shows that Malaysian purchasers are constrained in getting information relevant to the property that they intended to purchase.

Another source to obtain information regarding the conditions of the property in Malaysia is through valuation report prepared by the valuer. In Malaysia, property valuation is carried out for several purposes which can be divided into two main categories namely statutory and non-statutory valuation. Statutory valuation includes all those valuations for stamp duty, Property Gains Tax, compensation, and rating. Non-statutory valuation includes all those valuations for selling and buying, leasing, mortgage, and fire insurance (Ismail \& Buyong, 1998). Although a valuation report can provide general information about the property, this paper highlights that for the application for financing of a sub-sale property by an intended purchaser, the valuer is appointed by the bank hence has the bank's interest in mind instead of the buyer's. Besides, issues such as client's influence, valuation variation, unethical conduct, lack of enforcement on unethical valuers, expensive valuation fee and access to valuation report also affect the quality of the report and the 'truth' of the report in disclosing the real and true condition of the property. The primary weakness of valuation report in disclosing the conditions of the property lies on the purpose of valuation. A valuation report is required when a home purchase is being financed by a financial institution. The valuation is used to determine the fair market value of the property and only the general physical condition of the property. It does not disclose the property condition and systems in depth (Pyle \& Bartlett, 2016). The valuer usually reports on conditions that are apparent or observable. Unlike a building surveyor, a valuer does not test mechanical systems and major appliances (Hicks, 2014). However, it should be noted that a purchaser of sub-sale residential property who is not seeking any financial assistance would neither engage a valuer nor a building surveyor as it is not a statutory requirement. As such, the buyer would not be able to have any independent opinion as to the condition of the sub-sale residential property.

Another source of information in real property transaction is the home inspection report by the building surveyor. However, in Malaysia, this is not a statutory requirement. As such, it is not the general practice of the home buyers of sub-sale property. Home inspection process evaluates and reports on the physical condition of the structural and mechanical components of the property. As compared to the valuation report that focuses on the market price of the property, a building inspection report provides the buyer with the information regarding the condition of the property and its systems comprehensively (Pyle \& Bartlett, 2016). The prospective buyers primarily hire real estate inspectors to discover any defect or problem with the property they intend to buy and to ensure that repairs and rectification be made before the SPA is signed. Real estate inspection requires identification of health and safety problems through observation on the soils, foundation, construction, plumbing, electrical appliances, swimming pools, spas, roofing, heating, ventilation, and air conditioning (HVAC) (Burgess, 2003).

In Malaysia, the Institution of Surveyors, Malaysia has a Building Surveying Division of professional building surveyors who can provide a home or building inspection service. Also, the Association of Consulting Engineers Malaysia (ACEM) has a list of their members who offer home inspection services (National Residential Property Buyers Association, 2006). Here, the surveyors and engineers have the additional role of being inspectors - the surveyors inspect the earth and building condition while the engineers inspect the structural aspects of the building. As suggested by Aksah et al. (2016), Post Occupancy Evaluation (POE) should be a common practice in Malaysia. The POE is a systematic process of evaluating building after they have been built and occupied for some time. POE aims to identify the problems or defects in buildings and enhance the building performance in many facets including the process, functional, and technical performance. In Malaysia, while Valuation Standards were introduced in 2006, to date, there is no uniform building inspection standard, unlike Australia. However, the members of the Royal Institution of Surveyors Malaysia (RISM) are governed by the CP BS101: Code of Practice for Building Inspection Reports. Sadly, the survey conducted among 205 respondents from architecture, civil engineering, mechanical engineering, electrical engineering, quantity surveying, building surveying, property management and valuation backgrounds found that overall, responses obtained are disappointing when majorities 
of the respondents are 'not familiar' or 'not familiar at all' with the standards. For RISM Code of Practice for Building Inspection (CPBS101) (2011), the highest percentage recorded by the respondents are - those who are 'not familiar at all' (26.34\%); $23.41 \%$ of respondents are 'not familiar', 22.44\% 'familiar', 17.07\% 'quite familiar', and 10.73\% are 'familiar at all' (Ani et al., 2016). This implies that not only the public is unfamiliar with the home inspection, even building and construction professionals are not well-versed with the inspection standards. The scale of fees for surveyors and engineers do not provide a guideline on building inspection fee. Essentially, the fees would differ depending on various factors such as the type of the report, comprehensiveness, and details of the report and the size of the premises. It is to be noted that a building surveyor's service would increase the cost of the sub-sale residential property purchase transaction. According to Baharum et al. (2016), the professionals are regulated by the Valuers, Appraisers, and Estate Agent Act 1981. The Board of Valuers, Appraisers and Estate Agents has the power to ensure that the real estate professionals abide by the rules and guidelines as well as to strengthen the professional integrity and ethics. However, with the rapid change in the real estate business, there is a growing demand for more education, greater technical skills, workplace competencies, and personal effectiveness. A thorough review of the current competencies framework is necessary to increase the competencies of the building professionals.

\subsection{Vendor Disclosure Law: Potentials and Problems}

To mitigate the adverse effect of "as is" contract, many jurisdictions implemented vendor disclosure law. The legal obligation to disclose information regarding the condition of the property subject to the transaction is typically provided for in statutory provision. In the United States, many States have passed their respective vendor disclosure laws, such as section 1102.3 of the Civil Code (California), section 833(A)(2) of the Residential Property Condition Disclosure Act 1995 (Oklahoma), and section 765.20 of the Illinois Residential Real Property Disclosure Act 1994. In Australia, similar provision can also be found in the Tasmania, South Australia, and Australian Capital Territory. In Tasmania, section 86(1) of the Property Agents and Land Transactions Act 2005 provides for the vendor disclosure duty while in South Australia, it is stipulated under section 7(1) of the Land and Business (Sale and Conveyancing) Act 1994. In the Australian Capital Territory, the disclosure statement is required under section 67(1) of the Community Title Act 2001. Typically, a vendor disclosure provision will stipulate the obligation of the vendor to disclose and the time of disclosure (usually before the signing of the SPA). The law also stipulates the matters that need to be disclosed (differ from one jurisdiction to another but usually requires disclosure of facts materials to the conditions of the property) and the effects of nondisclosure (damages and other types of penalty such as fine and right to rescind the contract). The rationale of vendor disclosure is that in the sub-sale market of real estate purchase, asymmetric information creates a problem where owners have an incentive to sell products that have below average quality on the factor that it is not observable by the buyers (Akerlof, 1970). Owner-occupied housing markets also suffer from this problem (Glaeser \& Kallal,1997). A possible answer to this issue is by passing the law on seller disclosure. The law should provide the vendor's duty to inform the prospective buyer about known defects. Failure of which would provide redress to buyers once they have taken possession of the property and can obtain private information concerning product quality (Fishman \& Hagerty, 2003; Nanda \& Ross, 2008). Apart from the physical conditions of the property, this paper submits that non-physical aspect of the house as expounded by Aulia and Ismail (2016) should also be disclosed by the vendor. This includes aspects such as social interaction with neighbouring residents, safety, and security.

Despite the benefit of vendor disclosure law in providing a remedy to the buyers once the defect is discovered, vendor disclosure also received a fair share of criticism. Hashim et al. (2016) comment that having strong legislation alone is insufficient as it does not always guarantee that the laws and standards are upheld in practice. First of all, compensation is only available in the case of latent defect, whereas patent defect is not covered. A true latent defect is one that was not known to either the vendor or the purchaser at the time of sale, and, as a result, was not disclosed. If no evidence can be gathered to support a theory that the vendor had knowledge of a defect and deliberately failed to disclose it, then the vendor is not liable for the resulting costs of repairs. By contrast, patent defects are those which can be discovered by reasonable inspection (Chiarello, 2012). Secondly, courts have interpreted that although the property condition disclosure statement forms part of the agreement for a purchase and sale, it may not constitute a warranty. The primary objective of the disclosure statement is to notify the buyer about known problems with the property. Hence, it merely indicates that the statements therein are true according to the vendor's current actual knowledge. This is the position taken by the British Columbia Supreme Court in the case of Ward v. Smith (2001) 45 R.P.R. (3d) 154. Apart from that, there is also an issue concerning financial and time burden placed on the vendor to seek information that he is required to disclose from several government agencies. For example, information about encumbrances and restrictions must be obtained from the land registry, sewerage, and drainage plans, building records and building notice from the local government, and bankruptcy or civil suit records from the courts (Commercial and Property Law Research Centre, 2014).

Apart from that, some questions in the disclosure sheet may be complicated and arduous for the vendor who is an average layman to understand especially technical questions on zoning, unauthorised building works etc. Besides, there is also a tendency for disclosure statement to require the vendor to provide more than necessary information such as neighbourhood noise or nuisance (Shanks \& Ritson, 2017). Additionally, vendor disclosure law was also criticised because to enable a purchaser to claim damages for breach of disclosure duty; the purchaser bears the burden to prove that vendor must have had actual knowledge of the defect. A purchaser who receives a disclosure form has no guarantee that any disclosures will be made. In some circumstances, a vendor could simply claim to be unaware of any defects in the residence. Not only does the "unknown" option protect a vendor's ignorance, but it also offers little comfort to a purchaser in deciding as to whether to buy the property or otherwise. Therefore, if a vendor claims to be 
unaware of certain defects, then it will be up to the buyer to inspect the residence himself and discover whatever defects he can find (Gatlin, 1997).

\subsection{Conclusion}

This paper submits that a workable legal framework on vendor's disclosure law requires an equitable balance between the rights and interests of sellers and buyers alike. Ideally, the disclosure statement must be able to provide the purchaser with sufficient information to make a fully informed decision. On the other side of the coin, the vendor's disclosure duty should be restricted to provide information that they know, ought to know, or could reasonably obtain. The purpose of the disclosure is to inform the purchaser of matters relevant to the decision to buy the property hence it is submitted that the ideal time to deliver the statement to the prospective buyer when the offer to purchase is made by the prospective buyer. The disclosure should not occur at the later stage of the transaction. As for the effect of nondisclosure or breach of disclosure, it is the view of the authors that compensation in the form of damages is the appropriate measure. The penalty in the form of a fine should only be imposed in exceptional cases where fraud is involved as fine is meant as a deterrence. Alternatively, should the lawmakers decide not to adopt vendor disclosure law in Malaysia, this article suggests that lawyers and estate agents should incorporate a checklist on the condition of the property, which should be taken note by both the vendors and purchasers upon the negotiation of the sale and purchase of the sub-sale residential property. Hence, such an initiative could materialise if the Bar Council and the Association of Valuers, Property Managers, Estate Agents, and Property Consultants in the Private Sector Malaysia (PEPS) play an important role to educate and emphasize its importance to their members. It is hoped that such recommendations would balance the rights of the vendor and the purchaser of a sub-sale residential property in Malaysia and the purchasers' search for a Home Sweet Home would materialise. On this point, further research on the change of attitude and considerations taken into account by purchasers before purchasing a residential house would be a good way to uncover the benefits brought by the proposed checklist on the condition of the property.

\section{Acknowledgements}

The authors thank the National Institute of Valuation for sponsoring this research under the National Real Estate Research Coordinator (NAPREC) fund and the Research Management Centre, Institute of Research Management \& Innovation (IRMI), Universiti Teknologi MARA for managing this grant under the project code 100-IRMI/GOV 16/6/2 (0022/2016).

\section{References}

Abdullah, J., Ahmad, C.B., Sa'ad, S.R.M., \& Wahab, S.A. (2016). Public participation: KL Draft City Plan 2020. Asian Journal of Behavioural Studies, AjBeS, 1(3), Sep / Oct 2016 (p.33-41).

Akerlof, G.A. (1970). The Market for "Lemons": Quality Uncertainty and the Market Mechanism. The Quarterly Journal of Economics, 84, 488-500.

Aksah, H.,Ibrahim, M.N., Ismail, E.D., \& Rahim, S.H. (2016). Functional Performance from the Perspective of Building Management Team. Asian Journal of Quality of Life, AjQoL, 1(4), Nov. / Dec. 2016 (p.23-30).

Amstrong, T., \& Block, S. (2007). Beware: Property sold "as is" may come back to haunt the seller. Houston Business Journal, 37(36), 1.

Ani, A.I.C., Sairi, A., Johar, S., Razak, M.Z.A., \& Tawil, N.M. (2016). The practice of building inspection in Malaysian total asset management. Jurnal Teknologi, 78(1), $1-11$.

Aulia, D.N., \& Ismail, A.M. (2016). The Criteria of Residential Satisfaction in Gated Community: Medan City. Asian Journal of Behavioural Studies, AjBeS, 1(3) September/October 2016 (p.43-52).

Baharum, Z.A., Hwa, T.K., \& Salleh, S.M. (2016). Competency Framework for the Property Management Industry. 7th AicE-Bs2016Edinburgh, UK, 27-30 July 2016 / EBPJ, 1 (4), September 2016 (p.3-12)

Bearman Jr, L. (1960). Bearman Jr, L. (1960). Caveat Emptor in Sales of Realty--Recent Assaults Upon the Rule. Vand. L. Rev., 14, 541-579.

Burgess, R. (2003). Real Estate Home Inspection: Mastering the Profession. Chicago: Dearborn Real Estate Education.

Buang, S. (2016, November 15). Lindungi kepentingan pembeli rumah. Utusan Malaysia.

Cameron, J.G. (2000). A practitioner's guide to construction law. Philadelphia: American Law Institute.

Carper, D.L., \& McKinsey, J.A. (2011). Understanding the law. Ohio: Cengage Learning.

Chiarello, G. (2012). Buyer beware! Undisclosed defects in resale homes are a prevalent problem in today's real estate market. Novus Telum, 19(2), 1-3.

Cojocaz, J.A. (2005). "As is" clauses. Michigan Bar Journal, July 2005, 35-38.

Dayaratne, R. (2016). Creating Places through Architecture: Can environment-behaviour research help? Asian Journal of Behavioural Studies, AjBeS, 1(2), July/August 2016 (pp.1-12). 
Egercioglu, Y., Yilmaz, S., Cete, M., \& Cupi, R. (2015). Resident's Satisfaction to Evaluate Residential Environment before Urban Regeneration: Kizilay Neighborhood, Izmir. 2nd AQoL2015Izmir, Turkey, 09-14 Dec. 2015 / E-BPJ, 1(2) July 2016 (Pp. 145-155).

Fishman, M.J., \& Hagerty, M.K. (2003). Mandatory versus Voluntary Disclosure in Markets with Informed and Uninformed Customers. Journal of Law Economics and Organization, 19, 45-63.

Gatlin, L. I. (1997). Reforming Residentials Real Estate Transactions: An Analysis of Oklahoma's Disclosure Statute. Okla. City UL Rev., 22, 735-754.

Geltman, E.G. (2000). Recycling Land: Understanding the Legal Landscape of Brownfield Development. Michigan: University of Michigan Press.

Glaeser, E.L., \& Kallal, H.D. (1997). Thin Markets, Asymmetric Information, and Mortgage-Backed Securities. Journal of Financial Intermediation, 6, 64-86.

Hamilton, M. (2015). Caveat emptor (kinda): When as-is clauses are not "as is". Commercial Property Executive, (May 2015), 49-50.

Hashim, R., Ristak, N.D.M., \& Laili, N. (2016). Attitudes toward Environmental Democracy among Urban Communities. 7thAcE-Bs2016Taipei, Taiwan, 09-10 Apr. 2016 / E-BPJ, 1 (3), August 2016 (Pp.33-42).

Hicks, A. (19 August 2014). What's the Difference Between a Home Appraisal and a Home Inspection? Angie List. https://www.angieslist.com/articles/whats-differencebetween-home-appraisal-and-home-inspection.htm

Ismail, S., \& Buyong, T. (1998). Residential property valuation using geographic information system. Buletin Geoinformasi, 2(2), 249-266.

Lau, K.C. \& Abraham, S. (2015). Checklist of purchasing a subsale residential property in Malaysia. https://kclau.com/investment/residential-property-purchase-guidechecklist/ bukan article journal.

Leong, C.W. (2011). "As Is Where Is" in the Context of a Sale and Purchase Agreement. Newsletter, 10(10), 3.

Marsh, T. D., \& Solloway, R. G. (2005). Let the Seller Beware: The Slow Demise of Caveat Emptor in Real Property Transactions and Other Recent Developments in Indiana Real Property Law. Ind. L. Rev., 38, 1317-1339.

Mohamad, M.H., Nawawi, A.H., Safian, E.E.M., \& Saleh, A.F.A. (2017). Characteristic Qualities Impacting Landed House Prices: Better homes, better livelihood. Environment-Behaviour Proceedings Journal, 5th AicQoL2017Bangkok, 25-27 February 2017 / E-BPJ, 2(5), March 2017 (p.287-297).

Mohit, M.A., \& Iyanda, S.A. (2017). Low-Income Housing in Nigeria: A liveability investigation. Asian Journal of Quality of Life, AjQoL, 2(6), Apr / Jun 2017 (p.43-51).

Nanda, A., \& Ross, S.L. (2008). The Impact of Property Condition Disclosure Laws on Housing Prices: Evidence from an Event Study using Propensity Scores. Connecticut: Department of Economics University of Connecticut.

Pyle, D., \& Bartlett, L. (2016). Inspection vs. appraisal. Arizona: Academy Mortgage Corporation.

Roark, B., \& Roark, R. (2013). Concise encyclopedia of real estate business terms. New York: Routledge.

Rosenthal, A. J., \& Phillips, R. S. (1996). Tell It Like It Is-Sellers' Duties of Disclosure in Real Estate Transactions under California Law. Golden Gate UL Rev., 26, 473496.

Saleh, A.F., Hwa, T.K., Majid, R.A., \& Mohamad, M.H. (2017). Attributes of Housing Mismatch Framework in Urban Areas. AicQoL2017Bangkok, 25-27 February 2017 / E-BPJ, 2(5), March 2017 (Pp.277-285).

Shanks, D. \& Ritson, K. (2017). Ontario, Seller Property Info Sheet (SPIS). Thunder Bay: Cheadles LLP.

Sufian, A., \& Rahman, R.A. (2008). Quality Housing: Regulatory and Administrative Framework in Malaysia. Journal of Economics and Management, 2(1), 141-156.

Weinberger, A. M. (1996). Let the Buyer Be Well Informed-Doubting the Demise of Caveat Emptor. Md. L. Rev., 55, 387-424.

Wena, J., Ismail, F., Hashim, N., \& Romeli, N. (2017). Adaptation Criteria towards Quality Culture for the Malaysian Contractors. 5th AicQoL2017Bangkok, 25-27 February 2017 / E-BPJ, 2(5), March 2017 (p.79-83).

Yok, S.Y. (1999). Law governing the housing industry: A postscript. Malayan Law Journal Articles. 2 MLJ cxxxi. 